\title{
Effectiveness of Field Trip Learning Towards Batik Banten Curriculum in Elementary School
}

\author{
Minhatul Ma'arif ${ }^{1}$, Rizal Fauzi ${ }^{2}$ \\ ${ }^{1}$ English Education, STKIP Syekh Manshur, Indonesia \\ ${ }^{2}$ FISIPKUM, Universitas Serang Raya, Indonesia \\ 1minhatulmaarif45@gmail.com, ${ }^{2}$ sayarizalfauzi@gmail.com
}

\begin{abstract}
ב.
\section{Keywords:}

Field Trips, Batik Curriculum, Elementary School, Creativity.

ABSTRACT

This research is backed by the low creativity of elementary school students in the subjects of arts culture and Skills (SBK). The material taken is related to the batik curriculum in Banten in accordance with the PERGUB BANTEN 2014 that requires the entire school to integrate the local content curriculum of batik Banten. This research aims to increase the creativity of students in the local content curriculum in SBK subjects. This research uses class action research (PTK) with the number of students from 100 Grade 5 students elementary school who come from 4 (four) elementary schools in Panimbang, Pandeglang District by joining field trip activities. The results of the study were obtained through 2 (two) cycles, each cycle consists of 2 (two) meetings with a time allocation of 2 x 30 minutes. Based on the analysis of the research results obtained that there is no increase between the filed trip with the increase of student creativity on the field trips in integrating the curriculum batik. At the instructor's activity only increased by $0.5 \%$, while in student activity only increased by $13.5 \%$. Although the percentages are increasing, they remain in the "less" category, as they are below 70 . Likewise on the results of creativity, there is no increase in cycles 1 and 2, because it remains in the category of "less".
\end{abstract}

Article History:

Received: 29-06-2018

Revised : 27-08-2018

Accepted: 28-08-2018

Online : $30-08-2018$

This is an open access article under the CC-BY-SA license
https://doi.org/10.31764/ijeca.vli2.2121

\section{A. INTRODUCTION}

Today, learning outside of the classroom is much in demand by school students. It is no wonder that many schools do field trips to various locations that have an educational element. Many schools believe that field trips can improve skills and creativity, as there are many things that cannot be accomplished through the academic curriculum taught in the classroom (Fisher, Sharp, \& Bradley, 2017). The application of field trips in schools can affect the formation of students ' creativity in cultural and artistic arts subjects (Mega \& Giyartini, 2018). In Indonesia, many schools do field trips to various places that are synonymous with culture. This was done in an effort to integrate local content of curriculum 2013 on the subjects of cultural arts and crafts. The location of the field trips frequented are handicraft centres such as ceramic crafts, bamboo crafts, pottery, knitting, and Batik (Sukamti \& Sumanto, 2018).

In Banten Province, the centre of Batik handicraft many interested schools in field trips. It is in line with the exit of the governor of Banten number 15 year 2014 about the development of 
local content curriculum of Banten culture art. In the PERGUB in paragraph 2 (two) It is explained that the type of Banten culture must be integrated into the subjects of art and culture there 3 (three); Pencak Silat, Rampak bedug and batik of Banten.

In fact, research related to batik has been widely done in Indonesia. Based on the Bibliometric analysis that researchers do related to the keyword batik using the application Seforra obtained there are 74 articles that discuss batik since 2010-2018. The only thing that discusses about batik learning is still very few, there are only 5 (five) articles. At least the research related to the learning of batik, not if many craftsmen do batik training free of charge, such as the Company of Mothers (Mustika, 2018) and school teachers (Arini \& Abdullah, 2018). Furthermore, from the investigation of the batik related articles available, the majority describes the increase in the realm of (either psychomotor or cognitive) between before and after the study of batik (Rosania Ulfa, A Lathif, \& Khutobah, 2016). It is certainly natural, because learning in fact from those who do not know to know.

Although the whole thing says there is improvement but still, batik is not easy. There are many difficulties faced, such as the process of tasting and casting (Fauzie, Kholisya, \& Wijayanto, 2018). An article analysing the emotional relationships of students with batik states that the three have nothing to do (Hurriyati \& Mawarni, 2013). Especially if the learning of batik is associated with local content and creativity of students, no. In fact, creativity can be formed with the help of creative surroundings (Cinthya \& Kusuma, 2018).

In this article, researchers will discuss the effectiveness of field visits conducted 8 (eight) schools located around the batik workshop in Pandeglang district. These schools often bring their students, especially grade 5 Students for field science in the Cikadu Batik workshop. Thus, it attracts the attention of researchers to test whether the effectiveness of field visits to the site is batik in enhancing student creativity.

\section{B. METHODS}

This research uses class action research methods conducted over 2 (two) cycles. This study was held in January to March 2018 in the Batik Gallery of Cikadu Tanjung-Lesung with the study subjects as many as 4 (four) elementary schools in Pandeglang District and 6 (six) instructor of Batik. The object observed in this study in the form of increasing the creativity of learners before and after making a field trip. The tools used in this study are the equipment of the squinting, such as; stoves, candles, chemical dyes, soda and canting tools. The study consisted of two meetings (two-time field trips) with several stages; planning, implementation, observation and reflection. The instruments used in this study were two; 1) a learning tool consisting of students ' modules and worksheets and 2) data collection instruments consisting of the batik creative test that has been conducted by the expert test and observation sheet. Data is derived from the activity of instructors and students in the process of making batik during field trips as well as the results of the creativity of the student's batik.

\section{RESULT AND DISCUSSION}

\section{Stages of research}

This research was attended by 4 (four) elementary school in Batik Cikadu workshop in Pandeglang District in January-March 2018 with number of samples coming from Grade 5 school as many as 100 students. The study consists of 2 (two) cycles with 2 meetings, following discussion; 
a. Planning

At the planning stage, researchers perform a meeting on field visits twice according to the instruments that researchers have prepared in the form of a batik learning module. During the field visit, the students were given a small cloth or a plain white handkerchief to make the motif and taste. Afterwards, students carved out motifs using canting and giving colour to the creativity of students. Furthermore, students are given the evaluation to measure the level of students ' creativity in batik. Then students are given an observation sheet of student activity. All students ' activities are being observed by batik instructors and assisted by researchers. After all, researchers observe the activities of the instructor and the activities of students in accordance with the achievement of the local content curriculum in batik Banten. All of it is conducted researchers to fix it on a second cycle or on a two-time field trips.

b. Learning Implementation Phase

The time of field visit lasts two hours' lessons (2x35 minutes). The material provided is the correct and short way of deride to enhance the creativity of students. The following stages: a) orientation, At the orientation stage students are equipped with general knowledge regarding the proper batik procedures by the instructor; b) presentation, Once explained, the instructor performed a demonstration in front of the students about how to make the correct; c) exercise, At this stage student are guided to batik and make motifs on handkerchiefs according to the creativity of students, d) evaluates comprehension, As a form of feedback, the instructor gives input or direction from the evaluation of students; and e) self-training, At the second meeting, students are allowed to practice independently.

c. Observation stage

This stage is used by the instructor to observe and evaluate the results of the first LKS the students have performed. At this stage also instructors can already determine the level of student creativity temporarily.

d. Reflection Stage

The stage of reflection is an opportunity for students to present their work after conducting coaching and self-training. At this stage, instructors also provide feedback and opportunities for students to increase their creativity in the next cycle. The difference between the first cycle and the second cycle lies in additional material. In the second cycle, students are allowed to seek motive ideas according to their own knowledge which must be important based on the surrounding cultural elements. During the first cycle, students are guided by the instructor to make motifs from the motifs in the Cikadu gallery. These differences are made to inspire student creativity.

\section{Analysis of Research Results}

Analysis of research data researchers do by analysing the results of the instructor's activity data, student activity and the results of the student's creativity that has been done during the two cycles and 4 times the meeting (since each cycle is two meetings). The activity of researchers observes through the observation sheet that has been adjusted with the curriculum batik on local content. Here are the results of data that researchers can in two cycles. 
Table 1. Instructor Activity Sheet

\begin{tabular}{ccccc}
\hline Cycle I & Meeting & Percentage & Category & $\begin{array}{c}\text { Percentage } \\
\text { cycles }\end{array}$ \\
\hline \multirow{2}{*}{ I } & 1 & $40 \%$ & Less & $72 \%$ \\
& 2 & $64 \%$ & Less & \\
II & 1 & $65 \%$ & Less & $72,5 \%$ \\
\hline
\end{tabular}

Based on the analysis table on the instructor activity sheet it looks that on the first cycle does not ascending significantly. The ascent is only 0.5 . If viewed, in the first cycle of 1 st meeting, the instructor activity is only $40 \%$. The reason is that the instructor is still very hesitant to give students a batik lesson, because it usually only gives the material to the prehearings. Next on the second field trip, it is apparent that the instrumentation did not experience much of the change from the I-cycle in the 2nd meeting. It can be seen clearly that the 2nd Cyclist at the first meeting of only $65 \%$, not much different than the previous one. But, the increase occurred in the 2nd cycle at the second meeting of $80 \%$. Although it seems to increase from good to be very good but if calculated between Cycle 1 and cycle 2 is hardly any difference, only $0.5 \%$ only.

After conducting analysis of instructor activity, the observer also conducts analysis of student activity in batik class.

Table 2. Students Activity Sheet

\begin{tabular}{ccccc}
\hline Cycle I & Meeting & Percentage & Category & $\begin{array}{c}\text { Percentage } \\
\text { cycles }\end{array}$ \\
\hline I & 1 & $50 \%$ & Less & $47 \%$ \\
& 2 & $44 \%$ & Less & $60,5 \%$ \\
II & 1 & $58 \%$ & Less & \\
& 2 & $63 \%$ & Less & \\
\hline
\end{tabular}

Based on the table above can be deduced bring an insignificant improvement. It is similar to the activity sheet in Batik instructor. Cycle 1 at the first meeting of the student activity is $50 \%$, all of it is very reasonable because new students know the creativity of batik. Next at the second meeting, the student has decreased to $44 \%$, it is done by students to study independently, the instructor only monitors. In the 2 nd cycle, students have been getting feedback from the instructor so that at the first meeting the student activity is $58 \%$ and at the second meeting increased although insignificant is $63 \%$.

Next, the data on the creativity of batik before and after the class action was obtained:

Table 2. LKS Results Student Batik Creativity

\begin{tabular}{|c|c|c|c|c|c|c|}
\hline \multicolumn{7}{|c|}{ Creativity level of batik students } \\
\hline Cycle & & Person & $\begin{array}{c}\text { Process } \\
\text { (real-time action) }\end{array}$ & Product & Total & Category \\
\hline \multirow{2}{*}{ Cycle I } & 1 & $30 \%$ & $35 \%$ & $40 \%$ & $35 \%$ & Less \\
\hline & 2 & $55 \%$ & $30 \%$ & $50 \%$ & $45 \%$ & Less \\
\hline \multirow{2}{*}{ Cycle II } & 1 & $55 \%$ & $48 \%$ & $62 \%$ & $55 \%$ & Less \\
\hline & 2 & $65 \%$ & $50 \%$ & $54 \%$ & $56 \%$ & Less \\
\hline
\end{tabular}

(Kupers, Van Dijk, \& Lehmann-Wermser, 2018)

Based on the table above can be deduced take field trip cannot increase the creativity of students in batik, but not significantly. It can be seen from the increased percentage of creativity. Although there is an increase in total, but in categories does not increase. 


\section{CONCLUSION AND SUGGESTIONS}

Based on the data analysis field, there is no increase between fields trips with creativity in the local content curriculum batik. As for the percentage of each meeting, it does not change the category to be well on the student activity sheet and at the student's level of creativity. This is because the field trips do not use any special strategies in the process of learning. Students should be provided with special models at the time of the filed Trips (Nishio \& Kashihara, 2016) because the success of student learning is very influential on the learning model used (Ma'arif, 2018).

\section{REFERENCES}

Arini, N. W., \& Abdullah, K. (2018). Pelatihan Ketrampilan Membatik Bagi para Guru Sekolah Dasar di Gugus Sisingamangaraja Kramat Jati Jakarta Timur. Jurnal SOLMA, 7(1), 8. https://doi.org/10.29405/solma.v7i1.655

Cinthya, A., \& Kusuma, H. B. (2018). Meningkatkan Kreativitas Melalui Pelatihan Membuat Karya Dengan Memanfaatkan Botol Plastik Bekas. 2(1), 10-16.

Fauzie, M., Kholisya, U., \& Wijayanto, C. S. (2018). Membatik Untuk Anggota Majelis Taklim Salsabila. 01(02), 143-150.

Fisher, E. E., Sharp, R. L., \& Bradley, M. J. (2017). Perceived benefits of service learning: A comparison of collegiate recreation concentrations. Journal of Experiential Education, 40(2), 187-201. https://doi.org/10.1177/1053825917700922

Hurriyati, E. A., \& Mawarni, R. D. (2013). Kreativitas dan Ketahanan Emosional pada Siswa dengan Ekskul Membatik. Humaniora, 4(1), 37. https://doi.org/10.21512/humaniora.v4i1.3416

Kupers, E., Van Dijk, M. V., \& Lehmann-Wermser, A. (2018). Creativity in the here and now: A generic, micro-developmental measure of creativity. Frontiers in Psychology, 9(NOV). https://doi.org/10.3389/fpsyg.2018.02095

Ma'arif, M. (2018). The Influence of E-Learning Based On Edmodo and Computer Literacy Toward Learning Outcomes of Reading Comprehension in Class XI IPA of Daar El-Qolam II Senior High School. Cakrawala Pedagogik, 2, 159-168.

Mega, R., \& Giyartini, R. (2018). Pedadidaktika: Jurnal Ilmiah Pendidikan Guru Sekolah Dasar Pengaruh Metode Outdoor Learning terhadap Pembentukan Kreativitas siswa dalam pembelajaran SBdP. 5(4), 240-249.

Mustika, S. (2018). Melestarikan Batik Tradisional Rifa' Iyah Sebagai Identitas Budaya Komunitas Rifa' Iyah Preserving Rifa' Iyah Batik As Cultural Identity of Rifa' Iyah Community. 21(1), 29-42. https://doi.org/10.20422/jpk.v21i1.522

Nishio, K., \& Kashihara, A. (2016). Retrip: A Learning Environment for Augmenting and Presenting Knowledge from Field Trip. Procedia Computer Science, 96(September), 1304-1313. https://doi.org/10.1016/j.procs.2016.08.175

Rosania Ulfa, W., A Lathif, M., \& Khutobah, K. (2016). Peningkatan Kemampuan Motorik Halus Melalui Kegiatan Membatik Jumputan Pada Anak Kelompok B TK Asy-Syafa'ah Jember Tahun Pelajaran 2015/2016. Jurnal Edukasi, 3(3), 35. https://doi.org/10.19184/jukasi.v3i3.4307

Sukamti, \& Sumanto. (2018). Keragaman Jenis Dan Model Produk Home Industry Kerajinan Tangan Sebagai Sumber Belajar Di Di Sekolah Dasar. Sekolah Dasar: Kajian Teori Dan Praktik Pendidikan, 8285(1), 49-58. https://doi.org/journal2.um.ac.id 